\title{
The Current Trends of Augmented REALITY IN EARLY CHILDHOOD EDUCATION
}

\author{
Masyarah Zulhaida Masmuzidin and Nor Azah Abdul Aziz \\ Department of Creative Multimedia, Universiti Pendidikan Sultan Idris, \\ Tanjung Malim, Perak Darul Ridzuan, Malaysia.
}

\begin{abstract}
Augmented Reality has been widely used in various level of education such as higher-level education, secondary education (lower/upper secondary level), primary education, and in informal learning. However, the implementation in early childhood education is still limited. By using library research methodology, the objective of this paper is to investigate the existing work of augmented reality in early childhood education between 2009-2018. Based on the results, it shows that the publication of augmented reality in early childhood education increased slowly within these past ten years. It has been found that the main advantage of augmented reality is to enhance motivation. Early literacy has been found to be the most used topic with sampling less than 30 children. Finally, 'Marker-based' augmented reality has been widely used with mobile devices and in term of data collection methods, 'Test' has been used the most in this field of research.
\end{abstract}

\section{KEYWORDS}

Augmented Reality, Child Computer Interaction, Early Childhood Education, Preschool

\section{INTRODUCTION}

Augmented reality is a variation of virtual environments or virtual reality as it is more commonly called [1]. It can be defined as a system that allows real and virtual objects to coexist in the same space and be interact in real time [2]. This technology has been widely used especially in medical, training, military, advertising, and entertainment. In these recent few years, augmented reality gains a lot of attention among researchers in educational field due to its great features and advantages in enhancing teaching and learning. The features of the technology which according to $\mathrm{Wu}$ et al. [3], enables students to: (1) learn content in 3D perspectives, (2) ubiquitous, collaborative and situated learning, (3) learners' senses of presence, immediacy and immersion, (4) visualizing the invisible and (5) bridging formal and informal learning. By having these features, augmented reality has create a new way of learning, and making learning experience become more fun and engaging.

As aforementioned, the great features of this technology has made it widely use in the field of education. Due to its features, numerous educators and researchers have reported the advantages of augmented reality technology. For example, augmented reality can enhance learning, providing interaction, improving communication, triggering creativity and enhancing problem-solving skills. However, the biggest advantage of this technology can be seen from motivation perspective; especially in terms of: (1) fun, interest and enjoyment [4-6], (2) engagement [7-9], (3) satisfaction [10-11], (4) willingness to learn, (5) provide positive attitude [12], (6) attention [11], and (7) level of confidence [10]. 
The International Journal of Multimedia \& Its Applications (IJMA) Vol.10, No.6, December 2018

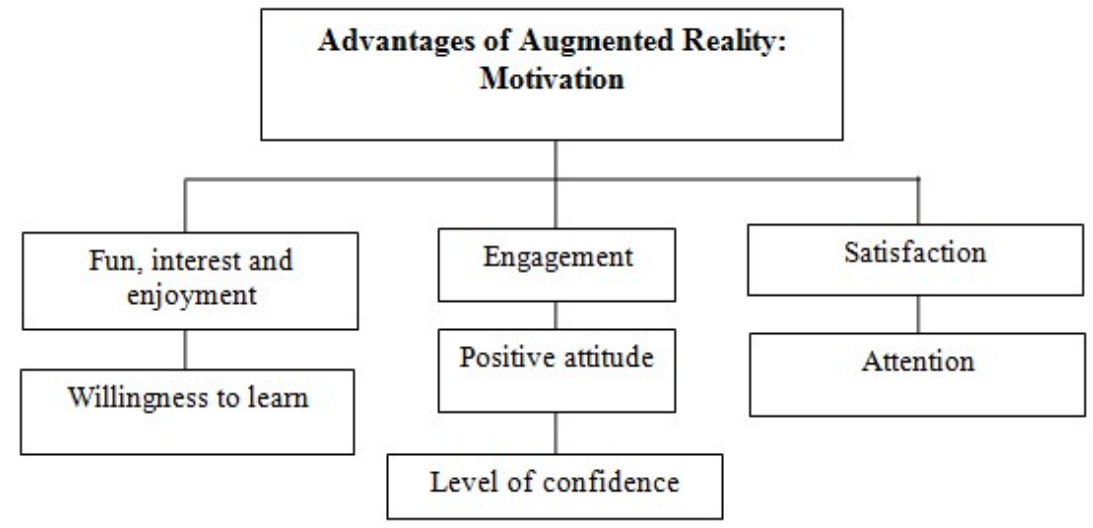

Figure 1. Advantages of augmented reality from motivation perspectives

According to Bacca et al.[13], augmented reality research has been conducted in various educational level such as higher level education (Bachelor), secondary education (lower and upper secondary level), primary education, and in informal learning. However, far too little attention has been paid for the implementation of augmented reality in early childhood education level [4], [14-17]. This statement is supported by Chen et al.[12] who reported the same results. Their review showed the same trends whereas augmented reality technology has been mostly applied in higher education settings and other compulsory education levels like primary and junior school and the least research has been done is with early childhood education.

As a user group that often being forgotten, therefore, it is very crucial for this research to be conducted in order to ensure that young users also can gain more benefits from AR technology as per claim by other researchers. Therefore, this paper reviewed several past studies related to early childhood education through the implementation of augmented reality technology.

\section{Purpose Of The Study}

The purpose of this study is to search for the existing works of augmented reality in early childhood educational level. It is important to know what research has been so far, not only to fill in the gap in the educational field of research but also to ensure that this user group is not left behind. The great potential of augmented reality shall not been wasted and should be shared among all users in all level of education.

Secondly, as mentioned by many scholars, augmented reality has many positive benefits in learning. Therefore, this study will investigate whether this learning benefit can be found from the early childhood educational perspective. Finally, this research will investigate the most used topic that has been researched, types of augmented reality, devices used with augmented reality application, research sample and the data collection method involved when conducting augmented reality evaluation with young children.

The research objectives for this study can be referred as follows:

1: To identify the existing works of augmented reality in early childhood education.

2: To investigate the advantages of augmented reality in early childhood education.

3: To identify the most used topic, types of augmented reality, device used with augmented reality application, research samples and the data collection method used for augmented reality in early childhood education. 
The International Journal of Multimedia \& Its Applications (IJMA) Vol.10, No.6, December 2018

\section{Methodology}

This study followed the four process as follows:

\subsection{STEP 1: DEVELOPING RESEARCH OBJECTIVES}

This study aimed to identify the current trends of augmented reality in early childhood education between years 2009-2018. The research objectives can be found in Section 2: Purpose of the study.

\subsection{STEP 2: IdENTIFY RELEVANT ARTICLES}

In this study, various databases like ACM, Science Direct, IEEE Xplore, ERIC and from Google Scholar have been used to search articles regarding young children's learning with augmented reality technology published from 2009 to 2018. The search terms like "Augmented Reality and preschoolers", "Augmented Reality and young children" and "Augmented Reality and kindergarten" were used.

\subsection{Step 3: Articles Selection}

The selected articles were examined by using a set of inclusion and exclusion criteria and determined whether they were related to the purpose of this study. By referring to Table 1, the first inclusion criteria is any paper published between 2009-2018 were selected and any articles that has been published before year 2009 were excluded.

Secondly, the selected articles focused on young children age 5-6 years and all papers involved young children with different abilities (special needs, autism, etc.) will be excluded. However, to find an article that really focusing on the exact age (5-6 years) as aforementioned was quiet impossible. Therefore, any paper that involving the children within the mentioned age range were included in this review.

Table 1. Inclusion and exclusion criteria

\begin{tabular}{|l|l|}
\hline \multicolumn{1}{|c|}{ Inclusion Criteria } & \multicolumn{1}{c|}{ Exclusion Criteria } \\
\hline Published paper between 2009-2018 & Published paper before 2009 \\
\hline $\begin{array}{l}\text { Young children aged 5-6 years old without } \\
\text { special needs and requirement }\end{array}$ & $\begin{array}{l}\text { Young children aged 5-6 years old with special needs } \\
\text { and requirement }\end{array}$ \\
\hline English language & Other language \\
\hline $\begin{array}{l}\text { Studies that describes application and } \\
\text { framework of augmented reality in early } \\
\text { childhood education }\end{array}$ & $\begin{array}{l}\text { Systematic Review, Editorial, Concept articles. Article } \\
\text { that used virtual reality etc. although augmented reality } \\
\text { mentioned in the study. Only terms appear in } \\
\text { references section. }\end{array}$ \\
\hline For educational purposes & For other purposes \\
\hline
\end{tabular}

Thirdly, articles that using other language than English were excluded. Fourthly, in order to fulfill the objectives of this research, therefore all articles that works on ideas, concept or review paper without any evaluation were excluded. Finally, only articles for educational purposes were included in this review.

\subsection{Step 4: Collecting, Summarizing and Reporting Research Findings}

After examination, 24 articles were found to be highly relevant to the purpose of this study. Examined articles were first coded into Microsoft Excel software. Frequencies and percentage of related data were presented in bar charts and tables. 
The International Journal of Multimedia \& Its Applications (IJMA) Vol.10, No.6, December 2018

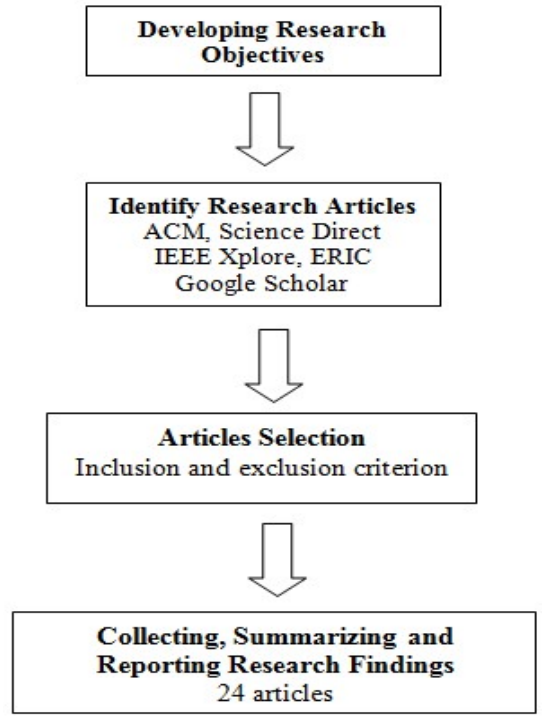

Figure 2. The process of paper selection

\section{Results And Discussions}

In this section, the results of conducting the review based on 24 articles are described and discussed.

\subsubsection{Results FOR THE EXISTING WORKs OF AUgMented Reality in EARLy CHILDHOOD EDUCATION}

By analyzing the year of publication of augmented reality in early childhood education studies, it has been found that the number of published studies has increased slowly especially during the first five years. While no study was found in 2009-2010, the highest number of published articles can be seen in year 2018. These results show that early childhood researchers are interested in exploring the augmented reality features and its advantages in early childhood education settings. Despite that, although a few additional researches have been found within these past ten years, however, the number of publication is not ample. A possible explanation of this result is that the technology could not be ready for being used by children since many aspects of interaction, such as the tracking and use of markers need to be solved [13].

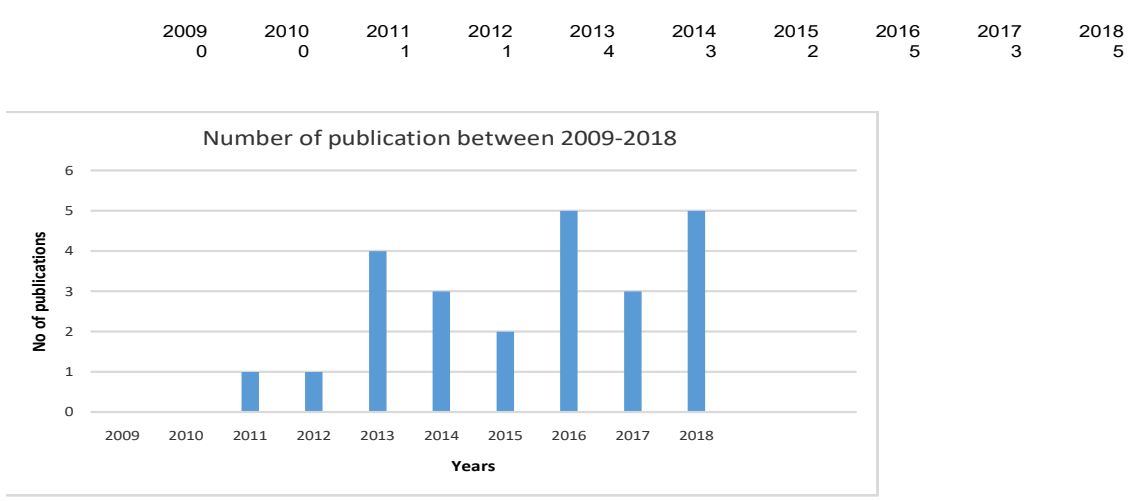

Figure 3. Numbers of publication since 2009-2018 
The International Journal of Multimedia \& Its Applications (IJMA) Vol.10, No.6, December 2018

\subsection{Results for the Advantages of Augmented Reality in Early Childhood EDUCATION}

There is a large volume of published studies that reported the advantages of augmented reality in education. However, it is important to get an overview of the real learning benefits of its implementation in early childhood educational settings. Table 2 shows the results of the reported advantages identified in the studies analyzed.

There are six advantages of augmented reality has been reported such as:(1) increase achievement/performance/understanding, (2) enhance motivation, (3) develop positive attitudes and behaviour, (4) enhance social skills, (5) fun learning and (6) others. Since one study can report more than one advantages, therefore, each study can meet more than one category.

From the results, it can be seen that the major advantages reported in the studies is "enhance motivation" (28.57\%). Augmented reality has been reported can grab children attention [18-19], increase children interest and satisfaction [20]. Other than that, augmented reality has been claimed can "increase achievement / performance /understanding" (26.53\%). On the other hand, a few studies reported on advantages of augmented reality in early childhood education such as positive attitude, behavior development, cognitive load and empathy [20-23].

\subsection{Results for the Most Used Topic in Augmented Reality in Early Childhood Education}

According to Table 3, augmented reality has been used in various learning topics. When analysed the implementation of augmented reality by field of education, 'Early Literacy' has been found the most explored topic in augmented reality in early childhood education. This is contrast with other level of education (primary, secondary and high level education) which focused more on 'Science' subjects [13], [15-16]. The possible explanation can be seen due to the importance of teaching young children about early literacy such as alphabets, numbers and writing. Meanwhile, other studies have focused on topic like 'Storytelling', 'Art education', 'Religion education', and 'Native language'. On the other hand, in 'Others' category the research conducted is related to emotion, thinking, social behaviour and interaction.

Table 2. Advantages of augmented reality in early childhood education environment

\begin{tabular}{|c|c|}
\hline Advantages of augmented reality & Number of studies \\
\hline $\begin{array}{c}\text { Enhance motivation (attention, relevance, confidence, } \\
\text { satisfaction, engagement) }\end{array}$ & 14 \\
\hline Increases achievement/ performance/understanding & 9 \\
\hline $\begin{array}{c}\text { Enhance social skills (self-esteem, collaboration, } \\
\text { communication) }\end{array}$ & 5 \\
\hline Fun learning (fun, excitement, happiness, enjoyment etc.) & 4 \\
\hline Develop positive attitudes behaviour & 4 \\
\hline Others (reasoning, cognitive and empathy) & \\
\hline
\end{tabular}


The International Journal of Multimedia \& Its Applications (IJMA) Vol.10, No.6, December 2018

\begin{tabular}{|c|c|}
\hline Topics & Authors \\
\hline Science (Animals, Newton) & {$[7],[24-26]$} \\
\hline Storytelling & {$[20-21]$} \\
\hline Art education & {$[27]$} \\
\hline English language & {$[14],[23],[28-29]$} \\
\hline Native language (native alphabet) & {$[30-32]$} \\
\hline Religion education & {$[19],[33]$} \\
\hline $\begin{array}{c}\text { Early Literacy (Alphabets, writing, numbers, early } \\
\text { childhood activity) }\end{array}$ & {$[4],[6],[18],[34-37]$} \\
\hline $\begin{array}{c}\text { Others (emotion, thinking, social behaviour, } \\
\text { interaction) }\end{array}$ & {$[22]$} \\
\hline
\end{tabular}

Table 3. The use of augmented reality in different field of education

\subsection{Results for Types of Augmented Reality Used in Early Childhood EDUCATION}

There are three types of augmented reality: (1) marker-based augmented reality, (2) marker-less augmented reality and (3) location based augmented reality. Marker-based augmented reality need to use a marker to fix the position of 3D objects onto real-worlds images [38] while location based augmented reality follows much the same process but rather than identifying a marker, it assigns digital information to a set of grid coordinates [39].

Based on the review, it has been found that most of the research used marker-based augmented reality $(95.8 \%)$. The possible explanation for this finding is that marker-based augmented reality is easy to use and develop compared to other categories. The existing of software like Vuforia and Aurasma simplify the process of creating marker-based augmented reality. Meanwhile, the least type of augmented reality has been used is 'Marker-less augmented reality' and 'Location based augmented reality' $(0 \%)$. According to Sirakaya \& Sirakaya [16], this type of augmented reality was used less due to the lack of technical skills on the part of researchers in developing these applications.

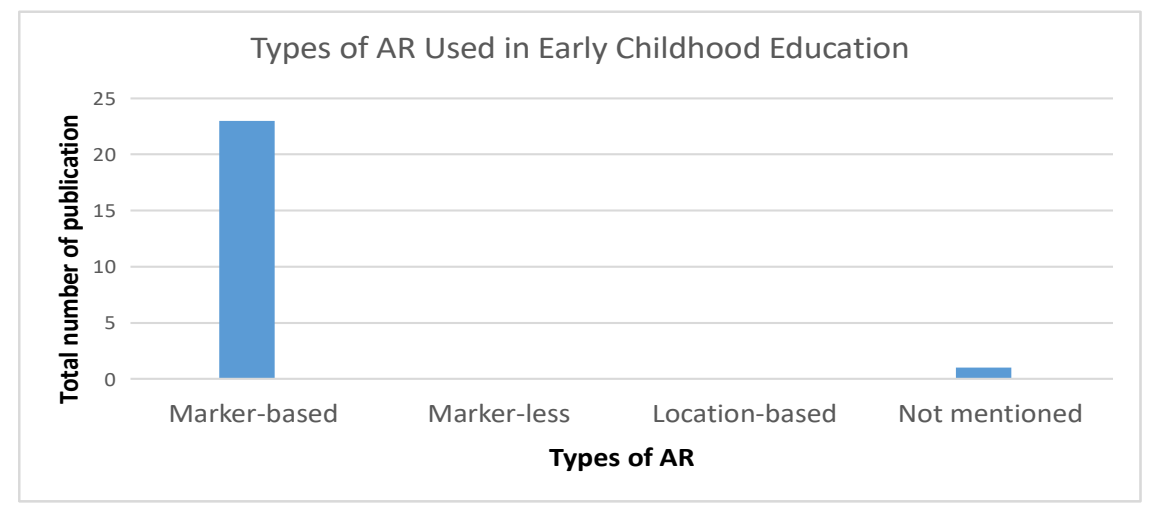

Figure 4. Types of augmented reality used in early childhood settings 
The International Journal of Multimedia \& Its Applications (IJMA) Vol.10, No.6, December 2018

\subsection{Results for DeVICE USED WITH AugMented ReAlity TeChNOLOGY}

Based on the review, 'mobile devices' (42.31\%) like smart phones and tablet have been used the most in augmented reality in early childhood education study and followed by 'webcam' (30.77\%). Similar results have been found in [16] and [40]. The reason for this finding is that mobile devices are economically [33], much more lighter and easy to use compared to other technology like Head Mounted Display (HMD).

According to Roberto et al. [34], the long duration using HMD would not be comfortable for children. Gil et al. [21] have supported this statement, where during their experiment with augmented reality group, they need to hold the HMD because the glasses were too bulky for the children. There were also few studies used different devices with AR technology like projector and interactive whiteboard.

\subsection{RESUlts FOR RESEARCH SAMPLES USED IN EARLY CHILDHOOd EdUCATION}

In this review, we considered four categories for the research samples, which are: (1) 30 or less than 30, (2) between 31 to 200, (3) more than 200, and (4) not specified. The result shows that, most research with young children involved 30 or less than 30 children in the studies and no research involved more than 200 participants. As mentioned by Bacca et al. [10], the possible explanation of these results is that greater number in research samples would increase the cost in term of providing device like smart phone and tablets to each of participant involved in the study. Other than that, one of the studies reported two different experiments and has been included in two different categories. Meanwhile, five studies did not specified the number of participant involved in their research and only aged of the children have been provided.

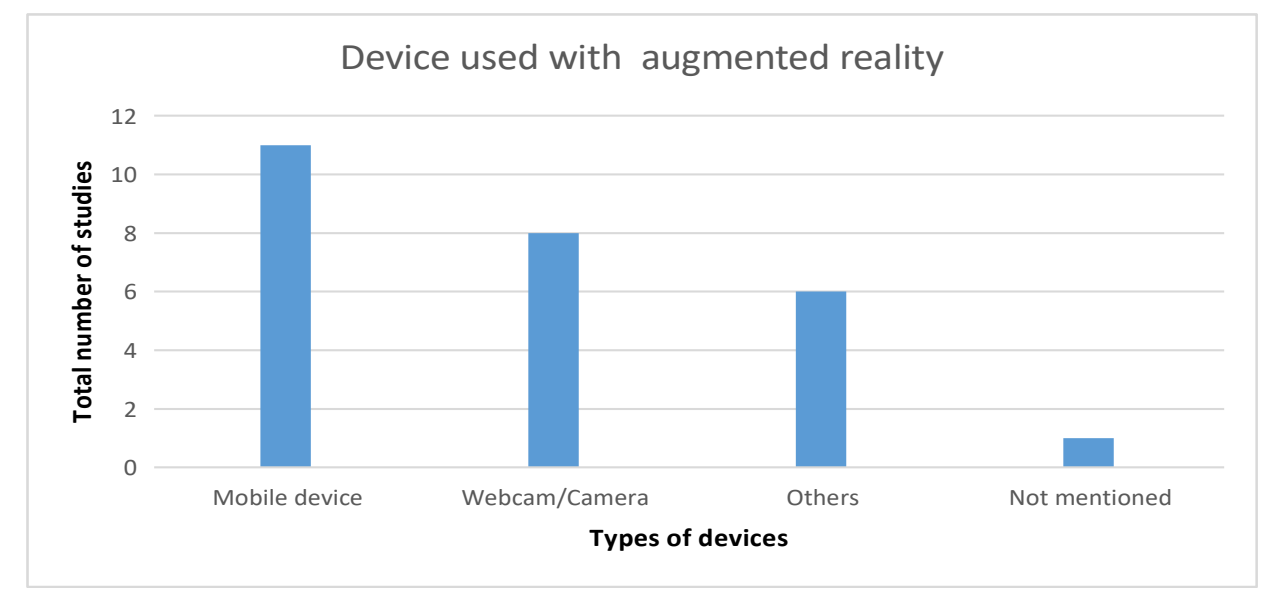

Figure 5. Device used with augmented reality

\subsection{Results for Data Collection Method Used in Augmented Reality in EARLY CHILDHOOD EDUCATION}

Figure 7 shows different tools used for data collection in augmented reality in early childhood education. The review found that most frequently used data collection method is 'Test' $(33.33 \%)$ and followed by 'Observation' $(24.44 \%)$. Meanwhile, there are also few studies that used 'Others' (11.11\%) tools like drawing intervention [34], report [36] and digital logs [24]. Since one study can use more than one data collection method, this study counts more than one category. 
The International Journal of Multimedia \& Its Applications (IJMA) Vol.10, No.6, December 2018

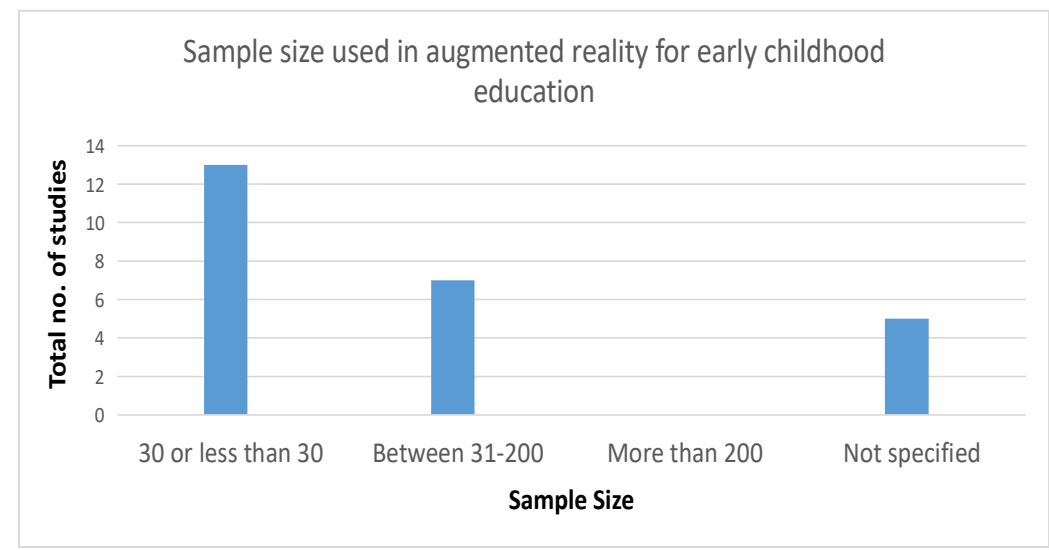

Figure 6. Research sample reviewed

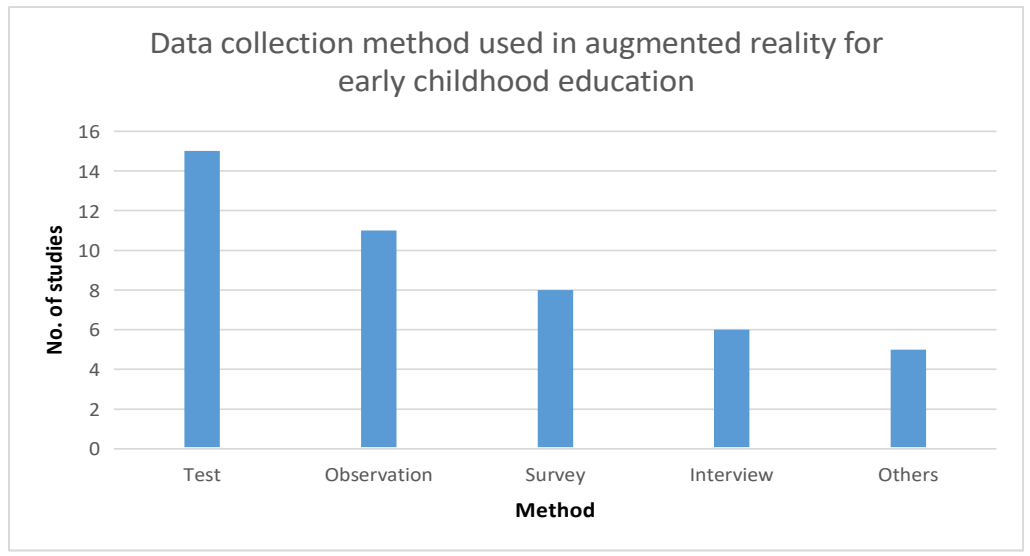

Figure 7. Data collection method

\section{FUTURE WORKS}

Young children is a special user group that has a unique characteristic. They can easily be motivated and they can easily be distracted and lost their attention during learning. This can be seen from the work of Rambli et al. [4], where as they revealed that after using augmented reality application for a while, children started to fell bored as they can predict what will happen next.

This statement shows that although augmented reality has been found to be a great tool in teaching and learning, however with ineffective design it is hard for researcher to sustain children attention and motivation. Based on their experience, Rambli et al.[4] suggested to embed element of surprise in the application so that children can become more engaging with technology and having more fun in learning. However, depending on element of surprise is not enough to maintain children motivation. Researchers need to have a deeper understanding about young children because as a digital natives, this user group have different preferences and needs. As mentioned by Markopolous et al. [41], children will use technology if they want to and if they dislike the technology, they will walk away.

Furthermore, based on the review, 14 out of 24 studies reported that children are engaged, satisfied, and paid more attention to their learning while using the augmented reality technology. 
The International Journal of Multimedia \& Its Applications (IJMA) Vol.10, No.6, December 2018

However, these studies did not mentioned which augmented reality element or features contributes the most to the children motivation in learning.

Therefore, in our future works, we will investigate on element that can enhance children motivation and this is what we refer as motivational design of augmented reality technology for young children. Designing a motivational technology is very important as it can improve children motivation to learn. We will implement Keller's Motivational Design Model by focusing on four main motivation elements, which are: (1) attention, (2) relevanc (3) confidence and (4) satisfaction.

\section{RECOMMENDATION}

We also would like to make the following recommendations:

1) Exploration in other subject

From this review, it has been found that early literacy has been well researched. However, the effectiveness of augmented reality technology in other field like moral education, native language, art and social skills and development are less explored.

Therefore, educators and researcher are suggest to investigate further on this subjects and topics.

2) Design with children for children

It has been found that most of the research in augmented reality used adult as the main designer. It is worth to highlight here that children participation is needed when designing augmented reality application for their use as children have their own likes, dislikes and curiosities and their needs is totally different compare to adult users.

Involving children in design is not a new practice. According to Read \& Markopolus [42], participation of children as designers is still understudied and explored. Therefore, we would suggest to other researchers to involve young children in augmented reality research, not only as a tester or user but also as a designer in their research work.

3) The effects of mobile devices in young children learning and health condition Children as a digital native communicate and interact with various technology every day.

However, few researches highlighted their concern on the usage of mobile devices in the classroom. As mentioned by $\mathrm{He}$ et al. [28], the use of mobile phone may distract children attention. This negative view was also reported in Huang et al. [27], whereas teachers and parents were concerned the side effects of using mobile devices with augmented reality technology in young children learning.

Therefore, further investigation can be done regarding on this issue and the influence of mobile phone on children's attention and health condition.

4) Exploration in different types of augmented reality

There are three types of augmented reality: (1) Marker-based, (2) Marker-less and (3) Location based augmented reality. Marker-based has been well used in augmented reality research not only in early childhood education level but in all educational level. 
The International Journal of Multimedia \& Its Applications (IJMA) Vol.10, No.6, December 2018

Therefore, we would like to suggest other researchers to conduct a further research by using marker-less and location based must be done.

\section{Conclusion}

This study has successfully investigates existing work of augmented reality in early childhood education. In total, 24 studies have been found from various databases like ACM, Science Direct, IEEE Xplore, ERIC and from Google Scholar. Based on the review, although it shows that

research in augmented reality in early childhood education has increased since the past few years, however the number of publication exists is still not ample.

Most of the researchers focus on motivation enhancement and the most used topic is early literacy. Marker-based AR and mobiles device has been choose widely in augmented reality in early childhood education. In terms of research sample, small participant has been used in the most study, which is less than 30 children. Test has been the most popular tools for data collection purposes in augmented reality in early childhood education.

As a conclusion, this review study can be utilized as a direction or references by other researchers in conducting studies especially in the augmented reality field by focusing early childhood education as the target users.

\section{ACKNOWLEDGEMENT}

Thanks to Faculty of Art, Computing and Creative Industry, Universiti Pendidikan Sultan Idris, Malaysia for the resources and support. A special thanks to my supervisor Associate Professor Dr. Nor Azah Abdul Aziz for her guidance in completing this research.

\section{REFERENCES}

[1] Azuma, R. T. (1997). A survey of augmented reality. Presence: Teleoperators \& Virtual Environments, 6(4), pp. 355-385.

[2] Azuma, R., Baillot, Y., Behringer, R., Feiner, S., Julier, S., \& MacIntyre, B. (2001). Recent advances in augmented reality. IEEE Computer Graphics \& Application, 21(6), pp. 34-47.

[3] Wu, H. K., Lee, S. W. Y., Chang, H. Y., \& Liang, J. C. (2013). Current status, opportunities and challenges of augmented reality in education. Computers \& education, 62, pp. 41-49.

[4] Rambli, D. R. A., Matcha, W., \& Sulaiman, S. (2013). Fun learning with AR alphabet book for preschool children. Procedia computer science, 25, pp. 211-219.

[5] Gopalan, V. (2016). A study of students' motivation based on ease of use, engaging, enjoyment and fun using the augmented reality science textbook. Revista de la Facultad de Ingeniería, 31(5).

[6] Yilmaz, R. M., Kucuk, S., \& Goktas, Y. (2017). Are augmented reality picture books magic or real for preschool children aged five to six?. British Journal of Educational Technology, 48(3), pp. 824-841.

[7] Rasalingam, R. R., Muniandy, B., \& Rass, R. (2014). Exploring the application of augmented reality technology in early childhood classroom in Malaysia. Journal of Research \& Method in Education (IOSR-JRME), 4(5), pp. 33-40.

[8] Jeffri, N. F. S., \& Rambli, D. R. A. (2017). Design and development of an augmented reality book and mobile application to enhance the handwriting-instruction for pre-school children. Open Journal of Social Sciences, 5(10), pp. 361.

[9] Hsu, Y. S., Lin, Y. H., \& Yang, B. (2017). Impact of augmented reality lessons on students' STEM interest. Research and Practice in Technology Enhanced Learning, 12(1), pp. 2.

[10] Bacca, J., Baldiris, S., Fabregat, R., \& Graf, S. (2015). Mobile augmented reality in vocational education and training. Procedia Computer Science, 75, pp. 49-58. 
The International Journal of Multimedia \& Its Applications (IJMA) Vol.10, No.6, December 2018

[11] Santos, M. E. C., Taketomi, T., Yamamoto, G., Rodrigo, M. M. T., Sandor, C., \& Kato, H. (2016). Augmented reality as multimedia: the case for situated vocabulary learning. Research and Practice in Technology Enhanced Learning, 11(1), pp. 4.

[12] Chen, P., Liu, X., Cheng, W., \& Huang, R. (2017). A Review of Using Augmented Reality in Education From 2011 To 2016. Paper presented at Innovations in Smart Learning, pp. 13-1.

[13] Bacca, J., Baldiris, S., Fabregat, R., \& Graf, S. (2014). Augmented reality trends in education: a systematic review of research and applications.

[14] Yilmaz, R. M. (2016). Educational magic toys developed with augmented reality technology for early childhood education. Computers in Human Behavior, 54, pp. 240-248.

[15] Li, J., van der Spek, E. D., Feijs, L., Wang, F., \& Hu, J. (2017). Augmented reality games for learning: a literature review. International Conference on Distributed, Ambient, and Pervasive Interactions, pp. 612-626.

[16] Sirakaya, M., \& Alsancak Sirakaya, D. (2018). Trends in educational augmented reality studies: a systematic review. Malaysian Online Journal of Educational Technology, 6(2), pp. 60-74.

[17] Yilmaz, R. M. (2018). Augmented reality trends in education between 2016 and 2017 years. In N.Mohamudally (Ed.), State of the Art Virtual Reality and Augmented Reality Knowhow (pp. 81-97). London: IntechOpen.

[18] Sidi, J., Yee, L. F., \& Chai, W. Y. (2017). Interactive english phonics learning for kindergarten consonant-vowel-consonant (CVC) word using augmented reality. Journal of Telecommunication, Electronic and Computer Engineering (JTEC), 9(3-11), pp. 85-91.

[19] Pradibta, H. (2018). Augmented reality: daily prayers for preschooler student. International Journal of Interactive Mobile Technologies (iJIM), 12(1), pp. 151-159.

[20] Han, J., Jo, M., Hyun, E., \& So, H. J. (2015). Examining young children's perception toward augmented reality-infused dramatic play. Educational Technology Research and Development, 63(3), pp. $455-474$.

[21] Gil, K., Rhim, J., Ha, T., Doh, Y. Y., \& Woo, W. (2014). AR Petite Theater: Augmented reality storybook for supporting children's empathy behavior. Mixed and Augmented Reality-Media, Art, Social Science, Humanities and Design (ISMAR-MASH'D), 2014 IEEE International Symposium, pp. 13-20.

[22] Bai, Z., Blackwell, A. F., \& Coulouris, G. (2015). Exploring Expressive Augmented Reality: The Fingar Puppet System For Social Pretend Play. Paper presented at the Proceedings of the 33rd Annual ACM Conference on Human Factors in Computing Systems, pp. 1035-1044.

[23] Pu, M., \& Zhong, Z. (2018). Development of a Situational Interaction Game for Improving Preschool Children' Performance in English-Vocabulary Learning. Paper presented at the Proceedings of the 2018 International Conference on Distance Education and Learning, pp. 88-92.

[24] Campos, P., Pessanha, S., \& Jorge, J. (2011). Fostering collaboration in kindergarten through an augmented reality game. International Journal of Virtual Reality, 10(3), pp. 33.

[25] Enyedy, N., Danish, J. A., Delacruz, G., \& Kumar, M. (2012). Learning physics through play in an augmented reality environment. International Journal of Computer-supported Collaborative Learning, 7(3), pp. 347-378.

[26] Cascales, A., Laguna, I., Pérez-López, D., Perona, P., \& Contero, M. (2013). An experience on natural sciences augmented reality contents for preschoolers. International Conference on Virtual, Augmented and Mixed Reality, pp. 103-112.

[27] Huang, Y., Li, H., \& Fong, R. (2016). Using augmented reality in early art education: a case study in Hong Kong kindergarten. Early Child Development and Care, 186(6), pp. 879-894.

[28] He, J., Ren, J., Zhu, G., Cai, S., \& Chen, G. (2014). Mobile-Based AR Application Helps To Promote EFL Children's Vocabulary Study. Paper presented at the Advanced Learning Technologies (ICALT), 2014 IEEE 14th International Conference, pp. 431-433.

[29] Dalim, C. S. C., Dey, A., Piumsomboon, T., Billinghurst, M., \& Sunar, S. (2016). Teachar: An Interactive Augmented Reality Tool for Teaching Basic English To Non-Native Children. Paper presented at the Mixed and Augmented Reality (ISMAR-Adjunct), 2016 IEEE International Symposium, pp. 82-86.

[30] Chen, C. H., \& Su, C. C. C. (2013). An integrated design flow in developing an augmented reality game for enhancing children chinese learning experience. International Journal of Digital Content Technology and its Applications, 7(4), pp. 907.

[31] Bazzaza, M. W., Alzubaidi, M., Zemerly, M. J., Weruga, L., \& Ng, J. (2016). Impact of Smart Immersive Mobile Learning In Language Literacy Education. Paper presented at the Global Engineering Education Conference (EDUCON), 2016 IEEE, pp. 443-447. 
The International Journal of Multimedia \& Its Applications (IJMA) Vol.10, No.6, December 2018

[32] Motahar, T., Fatema, T., \& Das, R. (2018). Bornomala AR-Bengali Learning Experience Using Augmented Reality. Paper presented at the Proceedings of the 20th International Conference on Human-Computer Interaction with Mobile Devices and Services Adjunct, pp. 182-188.

[33] Yasin, A. M., Isa, M. A. M., \& Endut, N. A. (2016). Interactive prophet's storybook using augmented reality. Envisioning the Future of Online Learning, pp. 391-399.

[34] Roberto, R., Freitas, D., Simoes, F., \& Teichrieb, V. (2013). A Dynamic Blocks Platform Based On Projective Augmented Reality and Tangible Interfaces for Educational Activities. Paper presented at the Virtual and Augmented Reality (SVR), 2013 XV Symposium, pp. 1-9.

[35] Safar, A. H., Al-Jafar, A. A., \& Al-Yousefi, Z. H. (2017). The effectiveness of using augmented reality apps in teaching the english alphabet to kindergarten children: a case study in the state of Kuwait. Eurasia Journal of Mathematics, Science \& Technology Education, 13(2).

[36] Ati, M., Kabir, K., Abdullahi, H., \& Ahmed, M. (2018). Augmented Reality Enhanced Computer Aided Learning for Young Children. Paper presented at the 2018 IEEE Symposium on Computer Applications \& Industrial Electronics (ISCAIE), pp. 129-133.

[37] Cieza, E., \& Lujan, D. (2018). Educational mobile application of augmented reality based on markers to improve the learning of vowel usage and numbers for children of a kindergarten in Trujillo. Procedia Computer Science, 130, pp. 352-358.

[38] Ozdemir, M., Sahin, C., Arcagok, S., \& Demir, M. K. (2018). The effect of augmented reality applications in the learning process: a meta-analysis study. Eurasian Journal of Educational Research (EJER), pp. 74.

[39] Kipper, G., \& Rampolla, J. (2013). Augmented Reality: An Emerging Technologies Guide to AR. Waltham, USA: Sygress Publishing.

[40] Akçayır, M., \& Akçayır, G. (2017). Advantages and challenges associated with augmented reality for education: a systematic review of the literature. Educational Research Review, 20, pp. 1-11.

[41] Markopoulos, P., Read, J. C., MacFarlane, S., \& Hoysniemi, J. (2008). Evaluating Children's Interactive Products: Principles and Practices for Interaction Designers. San Francisco, CA: Morgan Kaufmann Publisher Inc.

[42] Read, J. C., \& Markopoulos, P. (2013). Child-computer interaction. International Journal of ChildComputer Interaction, 1(1), pp. 2-6.

\section{AUTHORS}

Masyarah Zulhaida Masmuzidin obtained her MSc in Creative Media Technology with Computer Animation and Special Effects from University of Bradford, United Kingdom. Currently, she is a $\mathrm{PhD}$ student at Faculty of Art Computing and Creative Industry, Universiti Pendidikan Sultan Idris, Malaysia. Her research interest includes Interactive Multimedia, Child Computer Interaction, Virtual Reality and Augmented Reality.

Nor Azah Abdul Aziz is an Associate Professor at Faculty of Art Computing and Creative Industry, Universiti Pendidikan Sultan Idris, Malaysia. Her research interest includes Gestural Interface Design, Child Computer Interaction, Multimedia Application Development, Islamic Spiritual Psychology, Information Technology, Internet/Web Filtering, Internet \& Society.
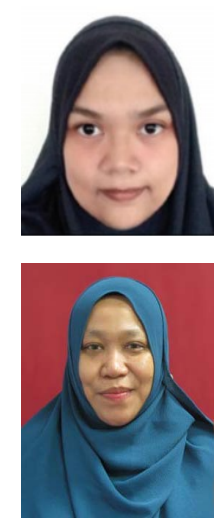